\title{
Journalistens och historikerns väg till miljöfrågorna, 1964-1969
}

Journalisten Barbro Soller och historikern Birgitta Odén utvecklade under 1960-talets gång ett starkt engagemang i miljöfrågor. Det gjorde att deras liv och karriärer tog nya vägar. Soller var med om att bygga upp ett nytt journalistiskt område. Odén verkade för att göra detsamma inom historieämnet. Deras respektive initiativ gav dock helt olika resultat. Där Soller nådde framgång och ryktbarhet, stötte Odén på motstånd som fick henne att avbryta sin satsning.

Barbro Soller och Birgitta Odén var framstående yrkeskvinnor i en tid då sådana var ovanliga. Världarna de verkade inom dominerades av män. År 1965 hade Dagens Nyheter 183 journalister anställda. Endast 30 av dem var kvinnor. ${ }^{194}$ I november samma år installerades Birgitta Odén som professor vid Lunds universitet. Alla hennes kollegor och alla hennes föregångare var män. Själv gjorde hon emellertid ingen affär av sin pionjärposition. ${ }^{195}$ Det gjorde inte heller Barbro Soller. De båda kvinnorna verkade genom exempel och aktivitet snarare än genom debatt och polemik.

Miljöfrågornas stora genombrott i Sverige följde, som vi har sett i de föregående kapitlen, två olika spår. Det ena var apokalyptiskt och globalt. Det andra mer lågmält och nationellt. Soller och Odén rörde sig huvudsakligen inom det sistnämnda. De tog miljöförstörelsen på största allvar, men talade inte om den i termer av ett hot mot mänsklighetens överlevnad. Deras fokus låg heller inte i första hand på överbefolkning eller massförstörelsevapen. Genom att följa dem i spåren framträder därför andra utvecklingslinjer än de vi har sett genom Hans Palmstierna, Karl-Erik Fichtelius och Rolf Edberg. 
Min undersökning av de två kvinnliga pionjärerna tar sin början i Barbro Sollers journalistik. Jag följer henne från det att hon anställdes som allmänreporter 1964 till det att hon lämnade Dagens Nyheter sommaren 1969. Under dessa år blev hon Sveriges första miljöjournalist. Men när hände det? Hur gick det till? Och vilken roll spelade hon i och för miljöfrågornas genombrott i Sverige? Därefter undersöker jag hur Birgitta Odén i samarbete med Försvarets forskningsanstalt (FOA), statsvetare och nationalekonomer utarbetade det tvärvetenskapliga projektet "Miljö, naturresurser och samhälle". Jag följer henne från det att de första stegen togs i maj 1967 till det att hon våren 1969 övergav projektet. Därutöver analyserar jag hur hon på lokal nivå verkade för att bygga upp en miljöhistorisk forskningsinriktning vid Historiska institutionen i Lund. Först ska vi dock vända blicken mot vårvintern 1964, den tidpunkt då Barbro Soller för första gången skakade om den svenska biociddebatten.

\section{Allmänreporter och miljöjournalist 1964-1966}

Lördagen den 22 februari 1964 rapporterade Barbro Soller att kvicksilver hade påvisats i svenska hönsägg. Dagens Nyheter gjorde det till huvudnyhet. På förstasidan publicerades ett fotografi av överläkaren och docenten Stig Tejning. Iklädd vit labbrock och med en pincett i högerhanden tittade han allvarligt in i kameran. I ingressen berättades det att höns som utfodrats med kvicksilverbetat utsäde, i motsats till andra djur, sällan blev sjuka. Hönsens motståndskraft utgjorde en fara för människor. "Det kvicksilver som hönsen äter går nämligen ut i äggen som vi äter", berättade Soller. Inne i tidningen förklarade hon ingående hur Tejning och hans kollega Ragnar Vestberg hade gått till väga. Hon var noga med att låta forskarna själva komma till tals. ${ }^{196}$

Fredagen därpå kom nästa larm. Soller rapporterade om en ny studie som visade att "även vi svenskar bär på en dos DDT i vårt kroppsfett". Bakom rönen stod laborator Gunnar Widmark. På förstasidan berättades det att han ingick i en större forskargrupp som hade utarbetat ett nytt förslag till svensk biocidforskning. Syftet var att "klarlägga den allmänna situationen och belysa de ekologiska effekter som användningen av kemiska bekämpningsmedel medför”. Ansökan hade utarbetats av Bengt 
Lundholm som underströk att flera av delprojekten var "av den art att de måste förverkligas omedelbart”. Det gällde särskilt frågan om kvicksilverförgiftning. "Vi har inte råd att förlora ännu ett år", slog han fast. ${ }^{197}$

Det Soller rapporterade om i februari 1964 var inte resultaten av några mångåriga vetenskapliga studier. Nej, det rörde sig om förstudier och ansökningar som tillkommit i kölvattnet av den intensiva svenska biociddebatten 1963. Genom Sollers försorg kunde forskarna föra fram preliminära resultat i offentligheten och resa krav på mer forskningsmedel. De kommande veckorna skrev hon fortlöpande om Tejnings och Vestbergs nya experiment. Deras studier visade bland annat att kvicksilvret samlades i äggvitan. I gulan var halterna betydligt lägre och i skalet fanns det inga spår. ${ }^{198}$ Forskarna pekade även på att hönor som ätit kvicksilverbetat utsäde inte lade sina ägg i redet. Detta kunde kanske förklara svenska fågelskådares rapporter om misslyckade häckningar hos havsörnen och andra fågelarter. ${ }^{199}$

Barbro Sollers miljögiftsartiklar väckte betydande uppmärksamhet i samtiden. De förflyttade tyngdpunkten från Rachel Carsons Tyst vår till studier av svenska förhållanden. Kvicksilveräggen debatterades på ledarplats och kommenterades av företrädare för olika myndigheter. Inom miljöhistorisk forskning har detta tagits till intäkt för att Soller 1964 blev Sveriges första heltidsanställda miljöjournalist. ${ }^{200}$ Det är en tolkning jag vill nyansera. Vid den här tiden skrev Soller nämligen om allt möjligt. Från körsång och konstutställningar till reportage om utländska celebriteter som besökte Stockholm. ${ }^{201}$ Miljöfrågor engagerade henne starkt, men till yrket var hon allmänreporter. ${ }^{202}$

Denna fas av hennes bana sträckte sig från 1964 fram till 1966. Under denna period skrev hon bland annat om när Charlie Chaplin besökte Stockholm och vad livräddare gjorde i Tylösand. ${ }^{203}$ Ett signum för henne var längre essäer om djur- och fågelliv. De publicerades vanligen i söndagsbilagorna och illustrerades med färgfotografier. Texterna vittnar om ett djupt naturintresse, men var knappast en form av miljöjournalistik. Det var djurens liv och beteenden som stod i fokus. Någon miljökris eller några miljögifter diskuterades inte. ${ }^{204}$

Sollers position på Dagens Nyheter blev dock med tiden allt starkare. Våren 1966 fick hon för första gången möjlighet att göra en stor reportage- 
resa utomlands. Tillsammans med fotografen Stig A. Nilsson reste hon en månad i Indien för att rapportera om den hotande hungerkrisen. Dagens Nyheter marknadsförde artikelserien i förväg och alla tre delarna slogs upp stort på förstasidan. Noterbart är att den första delen publicerades exakt en vecka efter Hans Palmstiernas "Malthus och världssvälten”. Men där Palmstierna var en vetenskaplig debattör var Soller en gestaltande journalist. Hon berättade om att det var torkans år i Indien. Jorden var sårig och full av sprickor. Flodbäddarna hade förvandlats till brända dalar och brunnarna sinade: "Jorden, människorna och djuren törstar som de inte gjort på hundra år." Anledningen var att monsunregnen uteblivit och att skördarna hade slagit fel över hela landet. Indien var beroende av hjälp från omvärlden. ${ }^{205}$

Soller lyfte fram att 46 av Indiens 480 miljoner människor hotades av akut livsmedelsbrist. För att säkerställa att hjälpen nådde fram till dem byggde myndigheterna nya vägar och dammar. Dessa nödhjälpsarbeten gav fattiga familjer en chans till utkomst. Förtjänsten kunde användas för att köpa mat till fasta priser. Med text och fotografier gav Soller och Nilsson den humanitära katastrofen ansikten. Ett av dessa var en familjefar som satt med ryggen vänd mot sin familj. Han hade gett bort sin dagsranson av bröd och vatten till hustrun och döttrarna. För att slippa känna hunger tittade han åt ett annat håll medan de åt. ${ }^{206}$

Den andra delen i serien riktade kritik mot hur de indiska myndigheterna hanterade krisen. Soller berättade om att detaljerade "hungerkartor" hade upprättats av myndigheterna där det gick att avläsa hur stor procent av befolkningen i ett område som hade drabbats av torka och missväxt. "Men avläser man verkligheten tappar man lätt aktningen för statistiken", skrev hon och lyfte fram en by som enligt kartorna hade skonats. Dit skickade regeringen uppköpare för att handla hundratals kilo spannmål. Men byborna hade inget överskott. De blev därför tvungna att köpa dyrt på marknaden och sälja billigt till myndigheterna. "Att uppköparen förläst sig på kartstatistik är mer än troligt", anmärkte Soller. I anslutning till reportaget intervjuade hon den indiske jordbruksministern. Han beskrevs som "en liten ettrig energisk man" med okuvlig optimism. Hans mål var att få indiska bönder att odla enligt vetenskapliga principer. För detta krävdes jordreformer, traktorer, nya spannmålssorter, konstgödsel och 
kemiska bekämpningsmedel. Visionen var att Indien skulle vara självförsörjande 1970. Soller var skeptisk. ${ }^{207}$

Den avslutande delen i serien dominerade söndagsutgåvan den 15 maj 1966. Dagens Nyheter lyfte fram att artikelserien hade väckt starka känslor hos läsekretsen. Många ville hjälpa. Därför publicerades en sammanställning över pågående och planerade svenska hjälpaktioner dit läsarna kunde skänka pengar. ${ }^{208}$ Soller intervjuade och porträtterade premiärministern Indira Gandhi, dock utan kritisk udd. Gandhi var "en person med ett svårt jobb" som genomförde det "med äkta indisk värdighet". I samtalet resonerade de två kvinnorna kring vad västvärlden kunde lära av Indien. ${ }^{209}$ Mer brännande var artikeln om den pågående befolkningsexplosionen. Soller lyfte fram att Indiens population växte med en miljon människor i månaden. Hon betonade att det var en ohållbar situation. Alla åtgärder för att förbättra människors livsvillkor "kommer ätas upp av det stigande befolkningsöverskottet" om inte "åtgärderna koncentreras på just familjeplanering". Men hittills hade alla kampanjer varit verkningslösa. Trots att bortåt en miljon steriliseringar genomförts och 16 ooo familjeplaneringscentraler upprättats fortsatte Indiens befolkning att växa med oförminskad kraft. År 2000 beräknades det bo en miljard människor i landet. Prognosen förskräckte. ${ }^{210}$

Barbro Sollers roll i artikelserien "Det svältande Indien" var den engagerade reporterns. Hon hade ett personligt tilltal och drog sig inte för att leverera kritik och dra egna slutsatser. I detta var hon del av en större trend. Under 1960-talets gång skedde nämligen en förskjutning i journalistiska ideal: från speglande objektivitet till kritisk granskning. ${ }^{211}$ Förändringen sammanföll med att journalistyrket professionaliserades. År 1962 inrättades särskilda journalisthögskolor i Sverige och under decenniets gång försvagades även banden mellan de politiska partierna och pressen. Förändringarna öppnade upp för en mer självständig journalistroll. ${ }^{212}$ Detta kom att få stor betydelse för Barbro Soller och för miljöfrågornas genombrott i Sverige.

Efter återkomsten från Indien återgick hon dock för en tid till att vara allmänreporter. Det arbetade hon som under återstoden av 1966. Hennes artiklar kunde lika gärna handla om semesterfirare i Bohuslän och Oktoberfesten i München som nya miljölarm. ${ }^{213}$ Men tiden som generalist 
gick mot sitt slut. Miljö- och djurartiklarna blev under höstens gång allt fler och från januari 1967 var det uteslutande detta som hon skrev om. Barbro Soller var nu Sveriges första miljöjournalist. I denna roll skulle hon på nytt göra kvicksilver i kosten till förstasidesnyheter.

\section{Barbro Soller och kvicksilvergäddorna 1967-1968}

Lördagen den 21 januari rapporterade Barbro Soller att det uppmätts höga halter av kvicksilver i svensk insjöfisk. Bakom upptäckten stod Statens institut för folkhälsan som arbetade med en nationell kartläggning av fiskbeståndet. De pågående undersökningarna hade, enligt Soller, gett oroväckande resultat. I Sveriges största sjö Vänern hade forskarna funnit gäddor med upp till 1,4 milligram kvicksilver per kilo, vilket var långt över det uppsatta gränsvärdet på 1 milligram. Myndigheterna gick därför ut och avrådde från daglig konsumtion. Det framhölls dock att människor utan risk kunde "förtära fisk från detta och andra kvicksilverförorenade vattendrag en gång i veckan”. Soller ställde sig kritisk. Hon lyfte fram att gränsvärdet för andra livsmedel var satt till o,05 milligram kvicksilver per kilo. "Varför rekommenderar man då ett värde som är 20 gånger högre för fisk?” undrade hon. Svaret från professor Arvid Wretlind var att fisk anrikade kvicksilver snabbare än landdjur, varför man behövde räkna med ett högre naturligt utgångsvärde. Det fanns ingen anledning till panik, underströk han, eftersom svenskar i genomsnitt hade så låg fiskkonsumtion. Den nya rekommendationen var endast avsedd för människor med ensidig insjöfiskdiet. ${ }^{214}$

Soller lät sig emellertid inte lugnas. Hon följde undersökningarna av svensk insjöfisk noga och hennes reportage nådde gång på gång förstasidan. I mitten på februari 1967 hölls ett stort kvicksilvermöte på Regeringskansliet i Stockholm. Jordbruksdepartementet hade tillsammans med Socialdepartementet bjudit in sex forskare, däribland Stig Tejning. Från mötet rapporterade Soller att svensk insjöfisk hade 19 gånger högre kvicksilverhalt än havsfisk. ${ }^{215}$ Misstankar riktades mot industrin och studier pekade särskilt mot massafabriker. ${ }^{216}$ I mars rapporterade hon om Tejnings fortsatta forskning kring kvicksilverbetat utsäde. Studierna visade att personer som arbetade med kvicksilver 
kunde få obotliga skador. Soller menade att rönen borde få stor betydelse "för den pågående diskussionen om vilka kvicksilverhalter vi skall acceptera i fisk för försäljning". ${ }^{217}$

Parallellt med att Soller drev kvicksilverfrågan hade den svenska debatten om de stora globala framtidsfrågorna börjat ta fart. Hans Palmstierna och Karl-Erik Fichtelius skrev regelbundet debattartiklar på Dagens Nyheters kultursida. Rolf Edbergs Spillran av ett moln var på väg att tryckas i en tredje upplaga. I april korsades Sollers och Edbergs vägar. Det var första gången som den svenske Norgeambassadören intervjuades i svensk press med anledning av Spillran av ett moln. Den stort uppslagna artikeln presenterades som startskottet på en ny artikelserie: "Den hotade människan". Soller framhöll att Edbergs bok hade blivit en bästsäljare i vetenskapliga kretsar. I intervjun intog hon en tillbakadragen roll och lät Edberg lägga ut texten. Han lyfte fram att nationers välstånd "ofta mäts i antalet bilar, TV-apparater och telefoner", men graden av miljöförstörelse var, enligt ambassadören, en betydligt säkrare måttstock på "civilisation". Själv ansåg han att välstånd borde mätas på ett annat sätt: "Luft att andas i stället för gift att andas. Vatten att dricka i stället för gift att dricka." Edbergs skarpa uttalanden illustrerades av ett halvsidesfotografi i färg av en soptipp. ${ }^{218}$

Dagen därpå kom en uppföljande artikel. Soller intervjuade professorn i bakteriologi Carl-Göran Hedén som riktade skarp kritik mot politikerna och det politiska systemet. Det behövdes fler personer med Rolf Edbergs klarsyn, framhöll han. Mänsklighetens viktigaste frågor krävde ledare med insikt i artens biologiska situation. Problemet var att dagens politiker endast hade ansvar" inför sina väljare och inte inför sina väljares barn och barnbarn". Det gjorde att närliggande och dagsaktuella frågor prioriterades framför långsiktiga hot. Hedén lyfte särskilt fram befolkningsfrågorna och den överhängande globala livsmedelskrisen. För att lösa problemen ansåg han att forskningsresurser borde koncentreras till dessa frågor. Soller själv var, precis som i Edberg-intervjun, närmast osynlig i texten. Hon ställde korta frågor som Hedén besvarade utförligt. Någon kritik eller några personliga funderingar framförde hon inte. Hennes roll i artikelserien var att göra varningsrösterna hörda. ${ }^{219}$ 
Efter intervjun med Hedén publicerades det dock inga fler artiklar i serien "Den hotade människan". Förhållandet säger en del om hur Sollers miljöjournalistik bedrevs vid denna tid. Hon rörde sig snabbt från ämne till ämne och följde ingen utstakad plan. De kommande månaderna skrev hon bland annat om oljeutsläpp, skånska naturvårdare, återställande av igenslammade sjöar och inrättandet av en ny miljöingenjörsutbildning. ${ }^{20}$ Men det ämne som hon konsekvent återkom till var kvicksilverhalten i svensk insjöfisk. Hösten 1967 intensifierades hennes bevakning.

Fredagen den 13 oktober rapporterade Soller att storkonsumenter av Vänerfisk kunde drabbas av hjärnskador. Bakom larmet stod än en gång Stig Tejning. Han hade undersökt "blod och hår hos 54 extrema fiskätare kring Vänern", huvudsakligen yrkesfiskare och deras familjemedlemmar. Gruppen uppvisade i genomsnitt fem gånger högre kvicksilverhalt i sina blodkroppar än en kontrollgrupp. Tejning inskärpte att situationen var synnerligen allvarlig och att fiskerinäringen av nationella hälsoskäl riskerade att slås ut. Yrkesfiskarna stod inför en ekonomisk katastrof. Tejning framförde också, genom Soller, sina förhoppningar om att ytterligare medel skulle skjutas till så att hans forskningsarbete kunde drivas vidare. ${ }^{221}$

Det stora geografiska kartläggningsarbete som Statens institut för folkhälsan genomförde färdigställdes i mitten på oktober. Soller ansåg att det bekräftade alla misstankar om skadliga kvicksilverhalter. ${ }^{222}$ En månad senare sammanträdde Medicinalstyrelsen och Veterinärstyrelsen. De utförde saluförbud för fisk från ett fyrtiotal vattendrag. Dock inte från Vänern. Soller beskrev i skarpa ordalag beslutet som att Sverige som första land i världen nu inte följde världshälsoorganisationens rekommendationer om högsta tillåtna kvicksilverhalt i människoföda. ${ }^{223} \mathrm{De}$ kommande månaderna rapporterade hon från offentliga debatter och började även skriva ledarartiklar i frågan. ${ }^{224}$ Hennes linje var att de gränsvärden som hade satts upp var godtyckliga och att saluförbudet måste utsträckas. Med frågor och artiklar pressade hon myndigheterna.

Lördagen den 3 februari 1968 rapporterade hon i triumferande ordalag att "Folkhälsan medger fel om giftvärden för svenska insjöfiskar". Det fastslagna värdet gällde endast om man åt fisk en gång i veckan (något 
som alltså Soller hade rapporterat om ett år tidigare). Denna information saknades dock i det material som Veterinärstyrelsen hade skickat ut till landets hälsovårdsnämnder. Därför tog Soller nu saken i egna händer. Med sin artikel ville hon överlämna fakta till svenska folket. På sin sida hade hon forskare och miljödebattörer som Stig Tejning och Hans Palmstierna. ${ }^{25}$ Det nära samarbetet mellan miljöjournalisten Soller och delar av det naturvetenskapliga forskarsamhället var karaktäristiskt för miljöfrågornas genombrott i Sverige. Hon gav forskarna röst och publicitet, men drev också en alltmer självständig och kritisk linje gentemot vissa myndigheter och de forskare som arbetade där. Hennes position på Dagens Nyheter stärktes. Möjligheterna för henne att bedriva undersökande journalistik växte.

\section{Nya Lort-Sverige 1968-1969}

Barbro Sollers stora publika genombrott som miljöjournalist kom våren 1968 med reportageserien "Lort-Sverige 30 år efteråt”. Titeln knöt an till Ludvig "Lubbe" Nordströms välkända socialreportage Lort-Sverige från 1938, som hade visat hur fattiga människor i 1930-talets Sverige levde i smutsiga, dragiga bostäder tillsammans med vägglöss, loppor och kackerlackor. Reportaget skakade samtiden och kom att bli pådrivande för socialdemokratisk reformpolitik. År 1968 var emellertid Nordströms Lort-Sverige historia. Svenska hem hade på trettio år blivit rena och moderna. Men Soller hävdade att utvecklingen hade en mörk baksida. Smutsen hade i själva verket inte alls försvunnit. Den hade bara förflyttats ut i naturen. ${ }^{26}$

"Lort-Sverige 30 år efteråt" var ett nytt samarbete mellan Soller och fotografen Stig A. Nilsson. Våren 1968 reste de genom Sverige, likt de två år tidigare hade rest genom Indien. Tillsammans visade de upp och granskade missförhållanden. Alla de sju artiklarna slogs upp stort på Dagens Nyheters förstasida, vid ett par tillfällen med färgfotografier. Varje del inleddes med att en passage från Nordströms 30-talsreportage lyftes fram och jämfördes med samtiden. Särskild vikt lade Soller vid de miljömässiga konsekvenserna av moderna bekvämligheter som bilar, vattenklosetter, tvätt- och diskmaskiner. Bland annat porträtterade hon 
en småbarnsfamilj i Värmland och lät Statens institut för byggnadsforskning räkna på vad deras villaliv innebar för miljön.

I artikeln växlade Soller fritt mellan olika stilgrepp. Hon skrev i sagans form om hur den unga familjen lämnade sin trånga lägenhet för att flytta till den moderna villan. Det var "en mycket vanlig saga 1968", underströk hon, "överallt i landet gladde sig kvinnor och män över teknikens framfart i köken och badrummen." Maskinerna gjorde livet enkelt och rent. "Men alla goda sagor har ett troll eller i varje fall ett sorgligt kapitel", inskärpte hon. Så även sagan om det moderna svenska villalivet. Därefter övergick hon till att i saklig ton redogöra för hur familjen indirekt smutsade ner vatten, mark och luft. Precisa siffror angavs och jämfördes med hur det hade varit trettio år tidigare. Utvecklingen gick i en oroväckande riktning. Därför vädjade Soller till läsarna att inte använda fosfatrika tvättmedel eller installera avfallskvarnar. "Vi är alla med om att skapa den miljö vi lever i", skrev hon, "men vi kan förbättra den och stora krafter är i gång att minska dessa var mans bidrag till föroreningarna." Hon blickade förhoppningsfullt framåt, mot ett samhälle där sopor blev värdefull kompost och inte luftföroreningar. ${ }^{227}$

Ett annat reportage i serien fokuserade Stockholms stadsluft. På förstasidan visades en bild på en man från hälsovårdsnämnden. Han höll upp ett ursprungligen vitt papper som hade färgats svart av avgaser. Bakom honom trängdes bilar. Soller berättade att det för trettio år sedan hade funnits omkring 60 ooo motordrivna fordon i Stockholm. År 1968 var siffran 360 ooo. Bilavgaserna blandades med skorstensrök från oljepannor, värmeverk och fabriker. Det bästa skyddet mot Stockholmsluften var att hosta.

Soller framhöll att många människor hade vant sig vid den gradvisa försämringen av luftkvaliteten. Andra protesterade. Hon berättade att en växande grupp innerstadsföräldrar hade börjat uppvakta politikerna. De motsatte sig att deras barn skulle behöva växa upp i en hälsovådlig miljö. Därför krävde de ett omedelbart förbud mot bly i bensin, obligatoriska avgasrenare och att planerna på nya parkeringshus i city revs upp. Framför sig såg Soller en "alltmer vaksam opinion". ${ }^{228}$ Själv var hon våren $1968 \mathrm{i}$ högsta grad med om att bygga upp den. 
"Lort-Sverige 30 år efteråt" innehöll även reportage från jordbruk och industri. Soller kontrasterade de sanitära problemen med löss och flugor i 1930-talets svenska hem med det utbredda bruket av kemiska bekämpningsmedel på 1960-talet. Biocidfrågorna hade under lång tid engagerat henne. Kontakterna med forskarvärlden var goda. Men våren 1968 använde hon sig av ett i sammanhanget nytt journalistiskt grepp. Hon vände sig direkt till bönderna. Vad tänkte egentligen de som arbetade med odling och besprutning?

Småbrukaren Gösta Olsson från Videlycke i Skåne berättade att han, liksom många andra, hade överlämnat besprutningen till en maskinstationsföreståndare: "dagens nya bonde". Men i fjol hade han på eget bevåg slutat använda kvicksilverbetat utsäde och ändå fått en fullgod skörd. Soller berättade att Olsson inte var ensam om att ta saken i egna händer. Under säsongen 1966-67 hade frökontrollanstalten funnit att blott en tredjedel av den svenska stråskörden behövde betas och att endast 40 procent av denna tredjedel faktiskt blev betad. Bönderna hade, med Sollers ord, "inlett sitt tysta motstånd mot betningen, sedan de blivit alltmer medvetna om de svåröverskådliga följderna”.

Nästa person hon vände sig till var Henning Randau, direktör för en av landets största maskinstationer. Från sin bas i Teckomatorp ansvarade han för bekämpning av ogräs och ohyra på omkring 6 ooo hektar åkermark i nordvästra Skåne. På förstasidan poserade han iklädd heltäckande skyddsdräkt, gasmask och handskar. Framför honom stod dunkar med gift och bakom honom sträckte åkrarna ut sig. För Soller berättade han att den enskilde bonden inte längre hade möjlighet att följa med i utvecklingen. Det fanns 700-80o kemiska preparat på marknaden och utrustningen var dyr. Därför hade jordbruket blivit alltmer storskaligt och industriellt.

Randau blev dock ingen måltavla för kritik. Tvärtom framträdde han som ansvarstagande och framåtblickande. För Soller berättade han att nya organiska ogräsmedel, lika effektiva men mindre giftiga och enklare för naturen att bryta ned, var på väg att ersätta DDT. Dessutom riktade han kritik mot att det inte krävdes någon utbildning för att hantera gifter. Många maskinstationsföreståndare och sprutförare hade endast gått en kort tredagarsutbildning. Denna gav Randau inte 
mycket för. Han visade upp kursboken Kemiska bekämpningsmedel som enligt honom endast kemister kunde läsa med behållning. För unga lantarbetare var den mer förvirrande än klargörande. Men så satt det heller inga praktiker i den statliga giftnämnden. "När såg nämnden en åker senast?" undrade Randau. ${ }^{229}$

Den sista delen av reportageserien fokuserade på massaindustrin i Sundsvall där landets största skogsindustriella bolag, Svensk Cellulosa AB (SCA), verkade. Soller berättade om hur Ludvig Nordström, när han på 1930-talet kom till Sundsvall, hade imponerats av fabrikernas bolmande skorstenar. För honom var detta ett bevis på industriella framsteg. För Soller var det en massivt förorenande verksamhet. Hon rapporterade att SCA använde havet för att göra sig av med kvicksilver och fibermassor utan att ta hänsyn till de långsiktiga miljömässiga konsekvenserna. Först på senare år hade reningsåtgärder börjat vidtas. Men ännu återstod mycket att göra. ${ }^{230}$

Dagen därpå diskuterade Dagens Nyheters huvudledare Barbro Sollers reportageserie. Det slogs fast att hon hade tecknat "en mycket mörk bild” av miljövårdens aktuella läge. Många av de små framstegen, som upprättandet av reningsverk, var endast skenbara förbättringar. Under sin resa hade Soller inte funnit ett enda reningsverk som fungerade som det skulle. Ledarskribenten slog fast att de senaste årens allt intensivare miljödebatt hade gjort människor medvetna om problemens art och omfattning. Men vad ledde insikterna egentligen till? Det framhölls att endast en liten del av miljöförstörelsen berodde på slarv och okunnighet. Huvudorsaken var en annan. Det var ekonomiskt lönsamt att smutsa ned och billigt att använda gifter. "Vi får alla via livsmedelspriserna en liten utdelning", påpekades det. Situationen krävde genomgripande förändringar. Det nya miljömedvetandet behövde resultera i "en ny villighet att ta ekonomiskt ansvar". Genom höjda priser, avgifter, skatter och sänkta vinster kunde alla vara med och bidra till att sanera Lort-Sverige. ${ }^{231}$

Våren 1968 nådde Barbro Sollers reportage Dagens Nyheters många läsare. Året därpå vidgades läsekretsen ytterligare. Reportagen gavs då i omarbetad och utvidgad form ut som pocketbok med titeln Nya Lort-Sverige. Utgåvan var rikt illustrerad med Stig A. Nilssons svartvita fotografier, vilka fungerade som visuella bevis för det Soller berättade 
om. I förordet till boken underströks det dokumentära anslaget. Soller lyfte fram hur hon "sett, luktat, hört och hostat" sig igenom det nya Lort-Sverige. Med sin bok ville hon sprida information och skapa debatt. Därigenom hoppades hon bidra till "en snabbare lösning av svåra frågor". Miljöproblemen "är besvärliga", betonade hon, men "i Sverige har vi råd att anstränga oss för att rätta till dem”. Möjligheterna var stora att bli ett föregångsland som i framtiden kunde hjälpa andra länder "där tillgångarna tärts och förslitits ännu hårdare än hos oss". ${ }^{232}$

Nya Lort-Sverige fick positiva recensioner och trycktes i en andra upplaga 1970. Parallellt med att boken gavs ut gjorde Soller och Nilsson en sista stor reportageresa tillsammans. Den resulterade i artikelserien "Djurfabriken" som var en ingående granskning av den svenska köttindustrin. Den löpte från mars till juni, men marknadsfördes - och uppmärksammades - inte alls på samma sätt som "Lort-Sverige 30 år senare". Exempelvis var det endast den första delen i serien som tog plats på förstasidan. Reportageserien kom att markera slutet på Barbro Sollers tid på Dagens Nyheter. Sommaren 1969 lämnade hon tidningen för nya uppdrag. Hennes karriär som miljöjournalist var dock inte över. År 1972 anställdes hon på Sveriges Television för att bygga upp tv-nyheternas miljöbevakning. ${ }^{233}$

Miljöfrågornas stora genombrott i det sena 1960-talets Sverige var också Barbro Sollers. Genom sin journalistik sammanförde hon vetenskap med vardagsliv. I den mediala offentligheten var hon en unik kunskapsaktör som fyllde många olika funktioner. Till en början gav hon i första hand naturvetenskapliga forskare röst och uppmärksamhet. I sin roll på Dagens Nyheter kunde hon få kunskap att cirkulera och forskarlarm att tas på allvar. Med tiden fick hon själv en allt starkare och mer självständig position. Det var hon som såg till att kvicksilvergäddorna och det nya Lort-Sverige hamnade på förstasidorna.

Men miljöfrågornas samhälleliga genombrott utspelade sig inte enbart i offentlighetens ljus. Många av de människor som engagerades i frågorna verkade på andra typer av arenor. En av dessa var den nyblivna historieprofessorn Birgitta Odén. Genom hennes efterlämnade papper, och kompletterande intervjuer, har det varit möjligt för mig att rekonstruera hur Odén under sent 1960-tal sökte bygga upp en ny 
miljöhistorisk forskningsinriktning. ${ }^{234}$ Detta vid en tidpunkt då det inte någonstans i världen fanns ett miljöhistoriskt forskningsfält. ${ }^{235}$ Odéns ambition var att göra historievetenskapen mer samhällsrelevant och hjälpa politiker att fatta bättre beslut. Men hur kom det sig att hon, som fram till 1960-talets mitt hade ägnat sig åt 1500-talets statsfinanser, ville gripa sig an en av samtidens brännande frågor? Vad ansåg hon att historiker kunde bidra med? Och hur gick hon till väga för att bygga upp ett nytt forskningsfält?

\section{Två möten på Försvarets forskningsanstalt 1967}

Upprinnelsen till Birgitta Odéns miljöhistoriska initiativ står att finna på Försvarets forskningsanstalt (FOA). Våren 1967 hade man där börjat tala om miljöfrågor i säkerhetspolitiska termer. Bakom detta stod Martin Fehrm, generaldirektör och chef på FOA. Han var vid denna tid även ordförande i Naturvetenskapliga forskningsrådet och satt med i den pågående Naturresursutredningen. Fehrm tänkte sig att de modeller för systematisk framtidsplanering som hade utvecklats av FOA på det militära området också skulle kunna komma till användning på miljö- och naturresursområdet. För att genomföra detta krävdes dock samhällsvetenskapliga kunskaper och kompetenser. Därför bjöd han i maj 1967 in tre professorer till ett möte på FOA: statsvetaren Pär-Erik Back, nationalekonomen Assar Lindbeck och historikern Birgitta Odén.

På detta stadium fanns det inga planer på ett gemensamt forskningsprojekt. Fehrm var i första hand intresserad av att pröva etablerade systemteoretiska planeringstekniker på miljöområdet. För detta behövdes samhällsvetenskapliga data och kunskaper om politiska beslutsprocesser. De tre professorerna klargjorde dock att det underlag som Fehrm efterfrågade inte fanns att tillgå. Varken inom statskunskap, nationalekonomi eller historia hade det tidigare forskats på området. För att systematisk framtidsplanering skulle bli möjlig krävdes det därför nya forskningsinsatser. ${ }^{236}$

På mötet diskuterades huruvida deltagarna skulle gå samman och skriva en debattbok. Med en sådan ville man få politiker och allmänhet att fă upp ögonen för miljöförstörelsens allvar. Tanken var att boken skulle utmynna i en plädering för en kraftfull satsning på målinriktade 
forskningsinsatser. Något beslut fattades emellertid inte och nästa sammankomst på FOA ägde rum först den 27 november 1967. På detta andra möte spelade Birgitta Odén en avgörande roll. Hon hade nämligen fått i uppgift att sammanställa tre PM om hur arbetet skulle gå vidare. ${ }^{237}$

I dessa utgick hon från de övergripande visioner som Fehrm hade redovisat i ett PM som hade cirkulerat internt inom FOA. Han framhöll där att meningsfull och rationell samhällsplanering krävde att varje beslut fattades "med bästa möjliga kunskap om konsekvenserna av beslutet, men även och i första hand med en klar precisering av vad man vill uppnå med beslutet”. Det första steget i beslutsprocessen bestod därför av att fastställa målsättningen, värderingsgrunderna och restriktionerna. ${ }^{238}$

Nästa steg i processen handlade om att identifiera och studera de olika handlingsmöjligheter som fanns. Detta skulle ske genom planer och program där kostnader och konsekvenser specificerades. Betydelsen av "svårbestämbara faktorer" och "osäkerhetsområden" skulle lyftas fram och en nyckelroll skulle vigas åt riktade forskningsinsatser. Målet för denna forskning var att åstadkomma "förbättrade framtida beslutsunderlag". Dessa tre ord i Fehrms PM strök Birgitta Odén under och i marginalen till stycket antecknade hon:"Detta är det enda historia kan vara med i."239

Odéns marginalanteckning får sin förklaring i ett annat dokument där hon nedtecknat sina synpunkter på Fehrms PM. Hon skriver där att"allt i Fehrms plan avser prognoser. För detta är historia oanvändbart". Det hon ansåg att historiker kunde bidra med var "kunskap om hur samhället i dessa avseenden har fungerat - och fungerar" ${ }^{240}$ Det förflutna liksom den omedelbara samtiden var hon beredd att gripa sig an, men framtidsprognoser lockade inte. Hennes marginalanteckningar förebådade de slitningar som skulle komma att uppstå mellan FOA och forskargruppen.

Novembermötet var dock i första hand ett konstituerande möte och Odén inledde sin föredragning med att fastslå varför en arbetsgrupp nu bildades. Hon lyfte fram att "vi väl alla är djupt oroade av teknikens och välståndsutvecklingens följdverkningar" och underströk att diskussionen inte kunde begränsas till naturvetenskapliga och tekniska aspekter av problematiken. Det var lika viktigt att politikerna försågs med utredningar "rörande den ekonomisk-sociala-politiska sidan av saken". Hon pekade på tre vägar framåt för gruppen: författandet av en gemensam 
skrift, upprättandet av ett forskningsprogram, samt etableringen av gruppen som ett samordningsorgan. Det sistnämnda krävde dock "ett mandat direkt från regeringen", men den punkten i hennes PM togs inte upp till diskussion. ${ }^{241}$

I anslutning till förslagen formulerade hon ett antal diskussionsfrågor: gruppens förutsättningar, sammansättning, finansieringsmöjligheter och relation till olika myndigheter. Mest belysande var emellertid den diskussionspunkt som gällde huruvida gruppen skulle författa en gemensam skrift. Det var i detta sammanhang Odén frågade sig om situationen verkligen fordrade en sådan: "Eller har läget ändrats efter DN-debatten, Palmstiernas bok, Naturresurskommitténs betänkande och Naturvårdsverkets aktioner?" ${ }^{242}$ Reflektionen visar hur dagsaktuellt orienterad Odén och FOA-gruppen var och vittnar också om att den svenska miljödebatten på bara ett halvår hade omformats i grunden. Kunskaper och krisinsikter cirkulerade inte längre enbart i specifika kretsar, som på FOA, utan rörde sig nu med stor intensitet i offentligheten.

Birgitta Odéns andra PM fungerade som ett avstamp. Det var ett diskussionsunderlag för hur ett tvärvetenskapligt forskningsprogram skulle initieras. Hon framhöll där att de "naturvetenskapliga data som finns pekar på att vi står inför en kritisk punkt i samhällsutvecklingen". Studiet av miljöproblem kunde därför "inte inskränkas till en naturvetenskaplig granskning". Det som krävdes var ett "integrerat forskningsprogram" vilket tänktes bestå av en naturvetenskaplig-teknisk del och en samhällsvetenskaplig-ekonomisk. Hon underströk att samarbetet mellan dessa fält var själva "poängen med gruppens konsolidering". Den uttalade målsättningen var att åstadkomma ett förbättrat beslutsunderlag för politikerna. ${ }^{243}$

Förutsättningarna för "en satsning med maximalt utbyte" stod centralt i PM:et. Odén lyfte särskilt fram vikten av att gruppen ansåg "målet tillräckligt viktigt för att vilja göra ett personligt engagemang och leda yngre forskare som arbetar i programmet". Denna formulering tog hon själv, som vi kommer att se längre fram, ad notam. Vidare ansåg hon att det behövdes någon form av auktorisation, en administrativ ledning samt tillräckliga ekonomiska resurser. För att den samhällsvetenskapliga forskningen skulle bli meningsfull krävdes också ett generellt tillstånd 
att få ta del av "förvaltningens och departementens arkivmaterial". ${ }^{44}$ Novembermötet avslutades med att de närvarande bestämde sig för att gå vidare med den tvärvetenskapliga satsningen.

\section{Slitningar mellan forskarna och FOA}

Det tredje mötet på FOA gick av stapeln i februari 1968. Inför detta möte sammanställde någon, oklart vem, en arbetsplan för gruppen. I denna angavs det att "gruppens uppgift var att skapa en ny modell för värderingar i samhällsplanering genom överförande av inom FOA använd systemteoretisk analys till samhällssektorn”. Detta modellbyggande behövde dock föregås av ett forskningsstadium som skulle fokusera på "värderingarnas roll i beslutsprocessen, tillgången på relevant kunskap på olika beslutsnivåer och förhållandet mellan de beslutande organens värderingar och olika opinionsgruppers värderingar”. För att forskningsuppgiften skulle bli hanterbar avgränsades den till miljöproblematiken. ${ }^{245}$

Det skisserade forskningsprogrammet hade sex ämnesingångar: naturvetenskap, teknik, medicin, ekonomi, statskunskap och historia. För kompetensen på de tre förstnämnda områdena stod Svante Odén och Hans Palmstierna samt tekniska experter verksamma på FOA. Samordningen krävde ett omfattande planeringsarbete i nära samråd med "avnämarna". Med detta uttryck avsågs i första hand de båda generaldirektörerna Valfrid Paulsson på Naturvårdsverket och Martin Fehrm på FOA. ${ }^{246}$ Vid sidan av arbetsplanen cirkulerades också en något omarbetad version av Fehrms PM "Välfärdssamhällets planerings- och beslutsfunktioner". Där underströks vikten av att upprätthålla "den biologiska balansen" och att miljöförstörelse inte fick äventyra framtida generationers handlingsutrymme. ${ }^{247}$

Det går inte att ta miste på att ambitionsnivån för forskningsprogrammet var hög. Samtidigt gav inte arbetsplanen någon konkret vägledning för hur gruppen skulle gå från planering till forskning. I anslutning till mötet på FOA noterade Birgitta Odén att olika särintressen hade börjat visa sig och att medlemmarna i gruppen därför drog åt olika håll: naturvetenskaplig forskning; samhällelig forskning; forskningspolitik 
och forskningsorganisation samt prognostisk verksamhet. För att lösa motsättningarna ansåg hon att forskningsprogrammets avnämare Naturvårdsverket - borde avgöra vad som önskades, därefter skulle gruppen kunna omorganiseras med hänsyn till målsättningen: "Det som blir över får var och en själv organisera." Hon såg dock en överhängande risk för "en sprängning av gruppen" ${ }^{248}$ Alternativet var tydliga riktlinjer och en fokusering av forskningsinsatserna. På baksidan av papperet har hon skrivit att de som borde fatta beslut om detta var Valfrid Paulsson och Martin Fehrm eftersom de hade "kontakterna med politikerna". ${ }^{49}$ Hela detta stycke har hon dock kryssat över. Av andra dokument att döma framgår det också att Birgitta Odén inte var beredd att styras av FOA. Det tydligaste beviset på detta återfinns i ett brev daterat 20 februari 1968 till Erik Dahmén, professor i nationalekonomi vid Handelshögskolan i Stockholm. Med brevet ville Odén få till stånd ett informellt möte den 5 mars. Dahmén var genom Assar Lindbeck och Svante Odén underrättad om FOA-gruppens arbete om miljöfrågorna och hade av dem bjudits in att delta. Han hade ett särskilt intresse för miljöproblematiken och arbetade vid denna tid med att färdigställa debattboken Sätt pris på miljön. ${ }^{250}$ I brevet till Dahmén skriver Birgitta Odén uttryckligen att "vi som representerar forskare utanför FOA känner just nu ett stort behov att behandla ärendet tillsammans och utan FOA:s inblandning". ${ }^{251}$

Det informella mötet kom också att hållas på Handelshögskolan, men såväl Dahmén som Back hade förhinder. Dock närvarade Svante Odén, vilket visar att skiljelinjen gick mellan forskargruppen som helhet och FOA. ${ }^{252}$ I ett brev till Back uttrycker Odén lättnad över att gruppen börjat ta det praktiska planeringsarbetet i egna händer. Hon reste där frågan om FOA-kontakterna möjligen borde inskränkas till ett samarbete med överingenjör Erik Moberg som inte heller" vill kasta ut detta snabbt utan tycker vi bör arbeta med saken några år". ${ }^{253}$ I avslutningen konstaterar hon att hela saken äntligen kommit i ett läge som kändes lugnt. Breven pekar mot att forskargruppen och FOA arbetade med olika tidsperspektiv. Martin Fehrm ville ha snabba resultat, forskarna ville ha gott om tid. 


\section{Miljöhistoria i Lund med politik i fokus}

Parallellt med planeringsarbetet på FOA tog Birgitta Odén egna lokala initiativ. Den första person som hon involverade var Sverker Oredsson. Han var vid denna tid fil. lic. och arbetade med att slutföra sin doktorsavhandling om svensk järnvägspolitik under 1800 -talet. ${ }^{254}$ Ett centralt tema i denna var debatter kring allmännytta och egennytta. Temat gick igen på ett annat område: 180o-talets skogsfråga. Oredsson uppmuntrades av Odén att utforska detta närmare och i september 1967 författade han ett tresidigt PM med titeln "Miljövård och politik under 180o-talet". Här redogjorde han kortfattat för lagar, kommittéarbeten och politiska debatter. Han lyfte bland annat fram att man i en utredning från 1868 ansåg att "skogsförödelsen bidragit till den svåra missväxten $\mathrm{i}$ slutet på 1860-talet". ${ }^{255}$ Meningen har strukits under av Odén. Möjligen såg hon det som ett varnande - och därmed användbart - historiskt exempel.

Nästa belägg för att Odén hade börjat engagera sina kollegor och studenter är från februari 1968. Vid denna tidpunkt skickade hon en redogörelse till Naturvårdsverket över den planerade och pågående verksamheten i Lund. Grundforskningsplanen bestod av tre delar: trendanalys, idéhistorisk analys och opinionsanalys. Ansvarig för den förstnämnda var Sverker Oredsson som skulle behandla den politiska hanteringen av skogs-, vatten-, diknings- och avloppsfrågan under perioden 1850-1950. Den idéhistoriska analysen av natur- och miljöproblematiken 1890-1950 skulle utföras av fil. mag. Ingrid Millbourn och opinionsfrågorna utredas av docent Lars-Arne Norborg. Utöver detta informerade Odén Naturvårdsverket om att man avsåg att genomföra "målinriktad, tvärvetenskaplig forskning" kring valda politiska beslut i naturvårdsfrågor och deras effekter på samhället. Detta arbete skulle ske i samarbete med systemanalytisk expertis.

I redogörelsen framkommer också att licentianden Yvonne Bengtsson hade börjat fördjupa sig i 1850-talets skogsdebatt och att fyra kandidatstudenter hade påbörjat uppsatsarbeten. Ämnena för dessa var "Högern och strandlagen", "Rachel Carsons 'Silent Spring' och dess mottagande i svenska fackkretsar", "Mörrumsån och dess 
problematik" samt "1949 års skogslag och 1956 års diskussioner". ${ }^{256}$ Studenterna namngavs inte i dokumentet, men det framgår av titlarna - och det faktum att de explicit togs upp i kommunikationen med Naturvårdsverket - att Odén såg uppsatsskrivandet som en integrerad del av det större forskningsprojektet. Hon byggde lokalt genom att vägleda studenter och unga forskare mot miljöhistoriska teman.

En av dem som Birgitta Odén lyckades styra in på detta spår var Lars J. Lundgren. Han hade blivit amanuens 1967 och kort därefter uppmuntrats att börja doktorera. Valet av avhandlingsämne var emellertid inte självklart. Det enda som han var säker på var att han inte ville gå vidare med något han gjort tidigare. Odén tyckte att han skulle ta god tid på sig, eftersom han skulle hålla på med arbetet under många år. Det räckte inte att projektet var intressant rent vetenskapligt, ansåg hon, man måste känna för ämnet och verkligen vilja veta. Uppmaningen resulterade $i$ en tid av obeslutsamhet innan Odén begärde ett samtal. Från detta hade Lundgren, när jag intervjuade honom 2017, klara minnesbilder.

Birgitta Odén inledde samtalet med att säga att hon hade förstått att han var intresserad av aktuell politik, modern musik och annat som rörde sig i tiden. "Du verkar leva rätt mycket i nuet", sa hon, "och så är du samtidigt historiker." Lundgren instämde varpå Odén undrade om han inte skulle ta och tänka igenom någon aktuell fråga och dess historiska rötter. Därefter "kastade hon faktiskt själv fram det här med miljö" och använde sig av argumentet "du är ju så mycket ute och lufsar i naturen så du bör ju ha ett intresse för miljön". Samtalet väckte Lundgrens intresse. Han hade följt med i den pågående miljödebatten "men aldrig tänkt på det historiskt". ${ }^{257}$ Han började orientera sig i statliga utredningar och insåg snabbt att han var sitt avhandlingsämne på spåren.

Samtalet skedde någon gång tidigt 1968 och i det efterlämnade materialet nämns Lundgrens namn första gången i projektplanen "Natur och samhälle i svensk politik 1850-1967". Planen härrör från februari 1968 och är utformad som en ansökan till det statligt finansierade Humanistiska forskningsrådet. Eftersom ansökningstexten är ofullständig, och i senare dokument benämns som ett PM, har den sannolikt inte skickats in. Av forskningsplanen framgår att Odén vid denna tid arbetade på två sammanflätade sätt. Dels utarbetade hon 
avgränsade forskningsprojekt, dels engagerade hon unga forskare att ta sig an dem. Hennes egen roll var forskningsledarens. Det var inte tänkt att hon själv skulle göra något empiriskt arbete. ${ }^{258}$

Målet med det historiska forskningsprogram som planerades var att "nå kunskap om de huvudsakliga utvecklingslinjerna i problemkomplexet natur och samhälle under de senaste hundra åren". Särskild vikt lades vid hur "attityder och värderingar har utvecklats, när det gäller de enskildas skyldigheter och rättigheter gentemot samhället - och vice versa - i fråga om naturresurser och miljöproblem". ${ }^{259}$ De två mest utbyggda delstudierna var Sverker Oredssons trendanalys av skogsfrågan och Ingrid Millbourns idéhistoriska studie av de politiska partiernas ideologiska ställningstaganden i naturresursproblematiken 1900-1930. Det ideologianalytiska angreppssättet var centralt i båda projekten och Birgitta Odén planerade fler liknande studier, däribland en om partiernas ståndpunkter 1930-1960 samt en samtidshistorisk om 1960-talet. Även det tredje huvudspåret i forskningsplanen, opinionsutvecklingen, hade en idé- och argumentationsanalytisk inriktning. Där återfanns en studie av "Naturvårdsföreningarnas opinionsbildande verksamhet" och en annan av "Press-opinionen i naturvårdsfrågan under 1960-talet". Därutöver skisserades socialhistoriska studier av naturvårdsföreningarnas medlemsstock och huruvida ökad fritid ledde till ett ökat naturvårdsintresse. ${ }^{260}$

Utöver de konkreta projektbeskrivningarna innehöll ansökningstexten också en tresidig allmän inledning. I denna tog Odén sitt avstamp i det förindustriella Sverige där "kollisionerna mellan natur och samhälle" hade varit "relativt små och betydelselösa". Människorna hade i allt väsentligt levt inom naturens ramar och "omsorgen om kommande generationer fanns med i föreställningsvärlden", bland annat i hanteringen av skogsresurserna. Hon framhöll dock att det även i äldre tid hade skett "överexploatering av naturresurserna med katastrofala verkningar". Det sedelärande exemplet framför andra var det antika Medelhavsområdet, vars jordar hade utarmats till följd av "för hård betning och förstöring av skog". Hon underströk att denna förödelse inte hade berott på en "kortsiktig värderingsskala" utan skett på grund av "vetenskaplig okunnighet om långsiktiga konsekvenser". 
Detta exempel på naturresursmissbruk och miljöförstöring visade enligt Odén hur viktigt det var att "aningslösheten om förhållandet mellan natur och samhälle" skingrades.

I det industrialiserade samhället var detta viktigare än någonsin tidigare. Förhållandet motiverade projektets modernhistoriska fokus och dess intresse för ideologier, värderingar och politiska beslutsprocesser. Birgitta Odén framhöll särskilt att "välståndsideologins doktrin om den ökade konsumtionens sociala och ekonomiska välsignelser" var otillräcklig eftersom den inte tog hänsyn till externa effekter på miljön. Hon framhöll att de negativa konsekvenserna "först nu blivit uppenbara" och det var därför angeläget att undersöka hur vi hade försatt oss i denna situation. Hade vetenskaplig information saknats? Hade de politiska värderingarna varit alltför kortsiktiga? Hur hade beslutsprocesserna egentligen sett ut? ${ }^{261}$

Frågeställningarna ovan vittnar om att Odén lade avgörande vikt vid politiskt handlande. Det var genom politiska värderingar, planer och beslut som den historiska utvecklingen formades. I linje med dessa antaganden kunde historieforskning bli samhällsnyttig just genom att förbättra det politiska beslutsunderlaget. På miljö- och naturresursområdet var forskningen särskilt påkallad, eftersom kunskapsläget var så skralt. Anledningen till detta var, enligt Odén, att "en företeelse som inte framstår som intressant i samtiden och som inte heller i det förflutna samhället uppfattades som intressant, har inte känts omedelbart lockande som forskningsobjekt”. Detta hade förändrats i och med det samhälleliga kunskapsgenombrottet 1967. För historikerna var det därför angeläget att röra sig in på detta nya område där deras forskning faktiskt efterfrågades. Samhällsnyttig historieforskning kunde inte vända ryggen åt samtiden. Den skulle gripa sig an och historisera aktuella problem, enligt Odén. ${ }^{262}$

\section{Planeringsarbetet intensifieras}

I mars 1968 gick planeringsarbetet in i ett intensivare och mer fokuserat skede. De fyra professorerna - Odén, Back, Lindbeck och Dahmén hade täta kontakter med varandra och började på allvar arbeta mot ett gemensamt mål: en projektansökan till den nyinrättade Riksbankens 
Jubileumsfond ${ }^{263}$ Det praktiska arbetet skedde utan FOA:s medverkan, men det rörde sig inte om någon formell brytning. Tvärtom ansökte professorerna hos FOA om vardera 20 ooo kronor (cirka 170 ooo kronor i dagens penningvärde) för att sätta igång sina respektive forskningsverksamheter. Ansökningarna beviljades i april och Odén använde sina medel för att timavlöna några av de unga forskare som hon engagerat i projektet. Dessa fick i uppdrag att genomföra avgränsade arbetsuppgifter av betydelse för den övergripande forskningsdesignen.

Två av dessa var Hans Idén och Ingemar Norrlid som tillsammans genomgick en kurs i systemteoretisk analys. Därutöver excerperade de systemteoretisk litteratur för att undersöka om metoden tidigare hade tillämpats i praktisk miljövårdspolitik. En annan person som involverades var Kerstin Malcus. Hon skulle genom litteraturstudier gripa sig an frågan om de klassiska naturförstöringsfenomenen, däribland erosion, och orientera sig i de miljöhistoriska diskussioner som pågick i USA. I början av maj var det också tydligt att Lars J. Lundgrens forskningsarbete hade börjat ta fart. Han erhöll medel för att gå igenom litteratur och tryckta källor kring såväl vatten- och avloppsfrågan som dikningsfrågans historiska utveckling. Därutöver undersökte Arne Fryksén förändringar i naturskyddslagen på 1950-talet och Bo Huldt gick igenom Östersjöfrågans behandling i riksdagen. ${ }^{264}$

Tidigt i april tog Odén kontakt med Paul Lindblom, direktör på Riksbankens Jubileumsfond. Han meddelade att fonden var "överlupen av ansökningar" och därför inte var beredd att ta ställning till gruppens planer förrän i oktober. Då skulle fonden å andra sidan ha större ekonomiska resurser att röra sig med. Eftersom ansökan skulle gå igenom olika remissinstanser behövde den dock skickas in före midsommar. ${ }^{265}$ Detta tog gruppen fasta på och professorerna bestämde sig för att skriva ihop var sitt PM till nästa inplanerade FOA-möte den 6 maj. Tidsramarna för programmet sattes till fyra år, med start den 1 januari 1969. Det sökta anslaget var avsett för lön åt två-tre unga forskare inom varje delprojekt. Därutöver önskade man tillsätta en styrelse, bestående av de fyra professorerna, som skulle ha medel till resor, konferenser och litteraturinköp. ${ }^{266}$ 
Birgitta Odén intog en ledarroll i gruppens arbete. Hon ansvarade för den interna kommunikationen och skrev utkastet till den gemensamma inledningen. Dessutom är det uppenbart att hon vid denna tid hade fått saker att börja hända i Lund. Nationalekonomerna i Stockholm och statsvetarna i Umeå befann sig fortfarande på ett tidigt planeringsstadium. Inför majmötet på FOA cirkulerade Odén en tresidig redogörelse för sin verksamhet. Vad som är särskilt intressant med detta dokument är att de empiriska provborrningarna hon initierat redan hade gett resultat. Några av de unga forskarna hade lokaliserat konkreta historiska problem som de ville undersöka närmare.

Ett exempel på detta är Lars J. Lundgrens studier av vatten- och avloppsfrågan. Lundgren hade undersökt hur man i riksdagen under tidigt 1900-tal behandlade lagstiftningsfrågor på området. Vid denna tid fanns det en tydlig intressemotsättning mellan industri och bönder. Högermän ställde sig på industrins sida, medan liberaler - understödda av socialdemokrater - värnade de som drabbats av förorenade utsläpp. När förespråkarna för en skärpt politik fick en starkare parlamentarisk ställning under 1920-talet kom emellertid inga förändringar till stånd. Varför ebbade aktiviteten ut i passivitet? Frågan hade generell relevans och förtjänade enligt Odén att utredas närmare. Ett annat övergripande spörsmål rörde ansvaret för framtida generationer. Här stod Sverker Oredssons studie av 180o-talets skogsfråga centralt. Den långa omloppstiden i skogsproduktionen framkallade intressekonflikter. Hur skulle man värdera ekonomisk expansion i nuet mot framtida behov? Frågeställningen aktualiserades även i diskussioner av en annan naturresurs - malmerna. I motsats till skogen var dessa resurser emellertid ändliga vilket öppnade för intressanta jämförelser. ${ }^{267}$

Den som hade fått Birgitta Odén intresserad av malmfrågan var den socialdemokratiske politikern och tidigare finansministern Ernst Wigforss. Hon hade intervjuat honom i april månad 1968 och han hade då framhållit att högermän och socialdemokrater funnit varandra i just malmfrågan. Båda grupperna menade nämligen att "malmer borde exploateras i nuläget - utan hänsyn till framtiden - därför att man visste vad man nu kunde få ut för malmen, medan i framtiden värdet kunde bli mindre". ${ }^{268}$ Enligt Wigforss hade liberaler motsatt sig denna 
ståndpunkt och argumenterat för framtida generationers nyttjanderätt. Samtalet med Wigforss vittnar om att Odén inte tvekade att ta kontakt med politiker. Detta framkommer också i hennes presentation av det planerade Östersjöprojektet. Bo Huldts förstudier hade visat att tre specifika politiker av olika färg var tongivande i riksdagsdebatterna. Mot bakgrund av detta hade Odén upprättat kontakter med dem för närmare efterforskningar. I redogörelsen till FOA nämnde hon även fem studentuppsatser som förhoppningsvis skulle bli klara till hösten. Det uttalade syftet med dessa var att undersöka om en serie centrala problem i svensk miljöpolitik var lämpliga som case-studies inom det större forskningsprogrammet. ${ }^{269}$

Nationalekonomernas PM färdigställdes först efter mötet på FOA. I ett brev till Erik Dahmén, daterat den 14 maj, tackar Odén för PM:et och informerar honom om att hon ska "använda weekenden för att färdigställa inledningen och sedan skicka den på 'remiss' till er". ${ }^{270}$ Texten Odén skickade ut var fyra sidor lång och hon fick ett snabbt svar från Back som tyckte den var utmärkt. Han hade "inga ändringsförslag, inte ens formella". ${ }^{271}$ Lindbeck tyckte inledningen var "vettig", men reagerade starkt på den passage där Odén beskrev upprinnelsen till gruppen. I det första utkastet stod det att Martin Fehrm "var en av de första, som klart insåg denna frågas samhällsvetenskapliga sida". Detta har Lindbeck strukit över och i marginalen skrivit "Usch! Servilt!". ${ }^{72}$ Erik Dahméns kommentarer var huvudsakligen av formell karaktär, men hans förslag till omformuleringar var inte oväsentliga. I utkastet skrev Odén att Naturresursutredningen "blottade skrämmande perspektiv" och att miljödebatten därefter "antagit lavinartade proportioner". På Dahméns förslag ändrades detta till "blottade allvarliga perspektiv" och "blivit mycket livlig". ${ }^{273}$ Ändringarna vittnar om att Odén hade ett starkt känslomässigt engagemang i miljöfrågorna, men samtidigt var prestigelös nog att ändra sina formuleringar. I stort som smått följde hon Dahméns och Lindbecks ändringsförslag. 


\section{Ansökan, avslaget och forskargruppen Natur och samhälle}

Den 17 juni 1968 skickades den fullständiga ansökan in till Riksbankens Jubileumsfond. I sitt förord lyfte professorerna fram att deras planerade forskning tycktes dem ligga väl i linje med fondens uttalade syfte att "öka kunskapen om de verkningar, som tekniska, ekonomiska och sociala förändringar framkallar i samhället och hos de enskilda människorna" ${ }^{274}$ Ansökan bestod av fyra delar. Den första innehöll den gemensamma inledningen samt en beskrivning av styrelsens arbetsuppgifter och budgetposter. Därefter följde tre ganska olikartade presentationer av delprojekten. Där Odén hade en utförlig och argumenterande text på nio sidor hade Back en mer skissartad på tre. Tematiskt låg dock historia och statskunskap nära varandra. Det som skulle undersökas var den politiska beslutsprocessen och värderingarnas roll i denna. ${ }^{275}$

Det nationalekonomiska projektet hade en annan karaktär. För Dahmén och Lindbeck var empiriska undersökningar inte tillräckliga de tog sikte på teoriutveckling. Huvudproblemen som skulle undersökas var exploatering av naturresurser, externa effekter och ekonomisk planering. Målsättningen var att formulera en "teori för investering under osäkerhet" där man tog fasta på "vissa speciella egenskaper hos naturresurserna, t.ex. irreversibiliteter". Forskningen skulle genomföras i nära samarbete med naturvetare som kunde hjälpa dem att hitta lämpliga studieområden. Planen var fem sidor lång, men innehållsmässigt tät och förhållandevis konkret. Exempelvis specificerade man vilka forskare som skulle anställas och vad de hade för kvalifikationer. ${ }^{276}$

Det historiska delprojektet "Natur och samhälle i svensk politik 1850-1965" var dock det mest utvecklade. Odén hade byggt vidare på sitt utkast från februari månad och presenterade nu en sammanhållen forskningsplan. Inledningens historiska bakgrundsteckning och syftesformuleringar var i princip oförändrade, men forskningsdesignen hade förfinats och renodlats. I juni 1968 var det tydligt att de så kallade "trendstudierna" utgjorde kärnan i det historiska forskningsprogrammet. Dessa var nu sex till antalet och kan grovt delas in i två tematiska block. Ett första som kretsade kring den politiska hanteringen av naturresurser 
(skog, vatten och malmer) och ett andra sombehandlade opinionsbildningen och den statliga naturvården. Samtliga trendstudier gick ut på att "fixera, i vilka tankebanor - d.v.s. med vilken målsättning och vilken värdering - man under olika perioder sökt lösa natur- och miljöproblematiken”. Detta skulle genomföras med "sedvanlig historisk metod, utökad med kvantitativ metod och s.k. content-analysis". Eftersom många forskare skulle undersöka samma material skulle viss central excerpering ske, framför allt av tidningsmaterial. ${ }^{277}$

I det andra blocket av trendstudier skulle naturskyddsrörelsens uppkomst, sociala sammansättning och ideologiska utveckling undersökas. Särskild vikt skulle läggas vid övergången från "estetiskt motiverad naturvård till socialt och ekonomiskt motiverad naturvård". En angränsande studie av den statliga naturvårdsförvaltningens framväxt skulle också genomföras. Den sista trendstudien, pressopinionen i naturvårdsfrågor under 1960-talet, var en "närmast självklar del av undersökningen", men skulle inte genomföras förrän "vi nått en bättre distans till ämnet". I väntan på detta skulle dock ett antal sonderande studentuppsatser författas. ${ }^{278}$

De trendstudier som motiverades mest utförligt var skogsfrågan samt vatten- och avloppsfrågorna. I båda fallen fanns det tydliga konfliktlinjer och ideologiska motsättningar mellan olika grupper. Därför tänktes undersökningarna kunna bidra med generella insikter. Skogsfrågan beskrevs som ett "utomordentligt viktigt testinstrument för ideologiska motsättningar i naturresursfrågor" och vatten- och avloppsfrågan var "värd stor uppmärksamhet, eftersom den uppvisar flera karakteristiska drag" ${ }^{279}$ Formuleringarna vittnar om att Odén inte var ute efter det historiskt specifika utan sökte det allmänna. Målet var att nå kunskap med bärkraft på nuet. Då var det viktigt att studera situationer och processer som liknade samtidens.

Utöver trendstudierna fanns ett avsnitt om historiska fallstudier. Dessa skulle utgöra en gemensam resurs för forskningsprogrammet. Om samhällsvetarna, eller FOA, hade behov av historisk expertis kunde tvärvetenskapliga specialstudier genomföras. För närvarande planerades en studie om Östersjön och en om utdikning. Fallstudierna skulle följa en speciell mall i elva punkter som hade utarbetats i samråd med FOA. 
Därigenom kunde forskningen bli direkt användbar för prognostisk verksamhet. ${ }^{280}$

I projektbudgeten diskuterade Odén även formerna för det kollektiva forskningsarbetet. Hon framhöll att den i huvudsak skulle utföras i form av licentiandarbeten med stipendiefinansiering. Det var "emellertid nödvändigt att knyta mer permanent arbetskraft till projektet, om detta skall kunna genomföras på ett mera energiskt och målmedvetet sätt”. Detta ville Odén göra genom att anställa en forskarassistent med licentiatexamen som kunde ansvara för att leda och planera gruppens verksamhet. Personen skulle även disputera på ett till projektet knutet ämne. Därutöver påpekade hon att "historisk forskning av denna art kräver ett förhållandevis stort centraliserat insamlingsarbete i skilda källserier”. Detta arbete skulle utföras av timarvoderade studenter, men "kontroll av excerperingen och excerpisterna bör åvila en forskningsassistent". Den senare skulle vara en yngre forskare som inom projektets ram skulle licentiera. Odén uppgav att lämpliga personer fanns att tillgå vid Historiska institutionen, men nämnde inga namn. Eftersom tillgången till licentiandstipendier var osäker, ville hon också ha viss handlingsfrihet att efter behov omfördela anslaget. ${ }^{281}$

Det historiska forskningsprogram som Birgitta Odén hade utmejslat var i högsta grad en kollektiv satsning med unga forskare i centrum. På ett års tid hade hon gått från att diskutera behovet av samhällsvetenskaplig och historisk forskning kring miljöfrågorna på FOA till att initiera en lokal forskningsmiljö i Lund. De nära kontakterna med samhällsvetare, naturvetare, politiker och myndigheter innebar att forskningen hade potential att sätta avtryck långt utanför historieämnet. Intresset för miljöfrågorna hade dessutom ökat kraftigt i Sverige under året som gått. Men för att hennes planer skulle kunna realiseras krävdes finansiellt stöd. Förhoppningarna knöts till Riksbankens Jubileumsfond.

Vid sammanträdet i oktober 1968 bordlades emellertid ansökan. Av Odéns efterlämnade papper tycks det som att fonden varit "missnöjd med utformningen av de ekonomiska och statsvetenskapliga delarna". ${ }^{82}$ I början på 200o-talet gjorde Birgitta Odén dock själv arkivefterforskningar för att utröna varför ansökan inte hade beviljats. Hon fann då att de externa sakkunniga hade gett välvilliga rekommendationer, men att 
styrelsen inte hade följt dem. Om anledningarna till detta kunde hon bara spekulera. Hon hade dock klara minnesbilder av att fondens dåvarande sekreterare i bryska ordalag hösten 1968 hade meddelat henne att hon inte borde inbilla sig "att historiker skulle få pengar motsvarande en hel universitetslektorstjänst för att studera ett ämne som miljö”. Hon beskriver beskedet som "ett slag i ansiktet" och lyfter fram att Martin Fehrm på FOA hade känt likadant: "I viss mening var det ju hans projekt, hans idéer som fick avslag." 283

Men ärendet var bordlagt, inte avslaget, och i januari 1969 skickade Back, Dahmén och Lindbeck in utbyggda projektplaner. Det framgår av dessa att samhällsvetarna på allvar hade kommit igång med sina forskningsidéer under hösten 1968. Pilotstudier hade genomförts och förhoppningarna om ett större anslag var inte grusade. Odén var dock "starkt präglad av missmod efter första utfallet" och gjorde inga ändringar i det historiska delprojektet. ${ }^{284}$

Vid fondens nästa möte den 14 februari 1969 kom ärendet att bordläggas igen. Av samtida brevmaterial framgår det att Odén nu helt hade gett upp hoppet om extern finansiering. "Detta betyder slutet för vår grupp", skriver hon, "varken Back eller Dahmén kan efter ett år av förespeglingar hålla ihop sina grupper - samhällsvetare är eftersökta och kan ju inte heller förväntas leva på luft.” De unga forskarna i Lund var "ståndaktiga", men Odén hyste tvivel kring sin egen roll och framtid: "Hur länge ska jag orka dra lasset utan någon hjälp i form av sekreterare eller assistent?" Hon meddelade att hon skulle gå ned på låg nivå och därmed slippa "varje plikt att leverera något". ${ }^{285}$

I mitten av april 1969 kom så ett oväntat besked. Riksbankens Jubileumsfond hade beslutat att ge den nationalekonomiska delen av projektet finansiering. Detta kom samtidigt att innebära det definitiva slutet på gruppens gemensamma satsning. Från FOA:s sida lämnades en protestskrivelse in, medan Back och Odén inte var beredda att kämpa vidare. ${ }^{286}$ Odén var dock angelägen om att det miljöhistoriska initiativet i Lund inte skulle gå om intet. Någon form av fortsättning ansåg hon vara nödvändig, särskilt med tanke på de unga forskare som hon hade engagerat. I samråd med Sverker Oredsson kom hon fram till att forskargruppen "Natur och samhälle" skulle bildas. Själv tog hon 
dock ett steg tillbaka och överlämnade ledningsansvaret till Oredsson. Under 1970-talets första år träffades gruppen regelbundet någon gång $\mathrm{i}$ månaden, men det rörde sig inte om ett koordinerat forskningsprogram. Avhandlingsämnena låg en bit ifrån varandra och arbetsvillkoren för gruppens medlemmar såg mycket olika ut. Det var endast Lars J. Lundgren och Rune Ivarsson som forskade på heltid. År 1974 kom Sverker Oredsson att lämna forskningen för kommunalpolitiska uppdrag. ${ }^{287}$

Omständigheterna för Birgitta Odéns avhopp är inte helt enkla att klarlägga. Det framgår av det efterlämnade materialet, liksom av mina intervjuer, att hon fortsatte att i hög grad intressera sig för miljöfrågor och miljöhistoria. Det var dock först på 1980-talet som hon själv på allvar grep sig an problematiken igen, då utifrån ett didaktiskt perspektiv. Därefter kom hon också att delta i de miljöhistoriska konferenser som under 1990-talet började anordnas i Sverige. Lars J. Lundgren minns särskilt ett tal som hon höll på en konferensmiddag under tidigt 2000tal. I detta tal blickade hon tillbaka på sina tidiga forskningsidéer och berättade i drastiska ordalag om sitt beslut att byta spår: "Jag hoppade av gruppen. Det var bättre att överlämna den till en annan. Eftersom jag hade misslyckats så kapitalt och blivit idiotförklarad." De starka orden gjorde intryck på Lundgren som först vid detta tillfälle insåg hur hårt Birgitta Odén hade tagit avslaget. Han bad henne därför en tid efter konferensen att utveckla sina tankar och hon hade då sagt: "Jag var ung, jag var ny och jag ville satsa på ett nytt område.” Det negativa beskedet hade blivit för mycket: "Jag klarade inte det."288

Odéns starka känslor framkommer också i hennes skriftliga tillbakablick på projektet från år 2002. Där berättar hon med stolthet att Per Eliasson precis hade disputerat på "en skogshistorisk avhandling inom ämnet historia med tydliga tvärvetenskapliga grepp". Avhandlingen innebar att "smäleken från 1968/69 var avtvådd" och att "miljöhistoria i sin lundensiska, politiserade form" kunde gå vidare med tillförsikt. Därefter slog hon fast: "Idéer kan hejdas av resursbrist. Men de behöver inte dö. De kan återkomma med nya bärare och stimulerade av nya impulser från de många discipliner som har miljö på sin agenda." 289 Satsningen hade inte varit förgäves. 


\section{Kunskapsaktörer och nätverk}

Barbro Sollers och Birgitta Odéns historier ger oss en fördjupad förståelse för hur miljöfrågornas genombrott i Sverige gick till. Deras professionella engagemang understryker att det samhälleliga kunskapsgenombrottet involverade och aktiverade många olika sorters kunskapsaktörer. I Sollers fall accentuerades intresset för miljö- och naturfrågor. Hon blev under 1960-talets gång allt mer drivande i utvecklingen. Tidvis var det hon som satte agendan för den svenska miljödebatten. I Odéns fall kom miljöfrågornas genombrott att innebära en radikal nyorientering i hennes egen forskning, från 150o-talets statsfinanser till det moderna industrisamhällets naturumgänge. Därigenom sökte hon föra historievetenskapen närmare samtiden och göra den praktiskt användbar i samhällsplaneringen. Men de stora ambitionerna kom inte att förverkligas. Hennes egen karriär tog andra vägar.

Birgitta Odéns miljöhistoriska initiativ var dock inte resultatlöst. Flera av de studenter och unga forskare som hon engagerade kom att fortsätta på den inslagna vägen. Störst konsekvenser fick detta för Lars J. Lundgren som 1974 disputerade på avhandlingen Vattenförorening $i$ Sverige 1890-1921. Detta följdes av en lång karriär på Naturvårdsverket som kombinerades med ett miljöhistoriskt författarskap. Utan Odén hade detta inte blivit verklighet. Exemplet understryker att ett samhälleligt kunskapsgenombrott inte är ett abstrakt fenomen. Det är en högst konkret historisk process. Det innebär att människor prövar nya saker som får andra människor att göra nya saker. Händelsekedjor och liv skär in i varandra. Ingen människa är en ö.

Avgörande i sammanhanget är de större personliga nätverk som kunskapsaktörer ingår i. Genom att följa Soller och Odén har några sådana framträtt. Särskilt betydelsefullt var att de hade goda relationer med naturvetenskapliga forskare. Soller åtnjöt stort förtroende som förmedlare av nya rön. För kvicksilverforskaren Stig Tejning fungerade hon närmast som ett språkrör. Med Sollers hjälp blev hans förstudier och experiment förstasidesnyheter, vilket var betydelsefullt för att säkra större forskningsanslag. Birgitta Odéns viktigaste relation var till brodern Svante. Han utgjorde en direkt förbindelselänk till 
forskningsfronten och var även närvarande vid mötena på FOA. Det samhälleliga kunskapsgenombrottet skedde $i$, och genom, den här typen av nätverk. Vetenskap, politik och medier var i 1960-talets Sverige tätt sammanflätade med varandra. De historiska aktörer som förstod att utnyttja detta kunde få mycket att hända.

Det allra tydligaste exemplet på detta är Hans Palmstierna. I detta kapitel, liksom i de föregående, har vi sett hur hans namn dykt upp i alla möjliga sammanhang. Palmstiernas vittförgrenade samhällskontakter framkommer också av hans omfattande privata korrespondens. Efter det stora genombrottet hösten 1967 skrev människor från hela landet, med olika bakgrunder och yrken, till honom. Jag har tidigare lyft fram enstaka exempel, som författaren Sven Fagerberg och lekmannen Sören Gunnarsson. I nästa kapitel ska jag ta ett samlat grepp på Hans Palmstiernas bevarade korrespondens. Därigenom vill jag synliggöra det svenska samhälle som miljöfrågornas genombrott skedde i. Vad gjorde människor som fick upp ögonen för miljöfrågorna? Hur resonerade de kring sina nya insikter? Och i vilka ärenden vände de sig till landets främste miljödebattör? 